wanym w XVI wieku na sposób zachodni, w kościele Mariackim $\mathrm{W}$ Krakowie ${ }^{64}$ ).

Sobór Trydencki nie określił również bliżej miejsca przechowywania Najśw. Sakramentu ${ }^{65}$ ), mówiąc tylko ogólnie, że w "Sacrarium" należy przechowywać Eucharystię. Mimo to od czasów tegoż soboru uwidacznia się dążność do ujednostajnienia praktyki przechowywania konsekrowanych Postaci. Przyjmuje się i rozpowszechnia tabernakulum w kształcie szafki przytwierdzonej do środka oltarza. Ostatecznie tego rodzaju tabernakulum zostało przepisane i nakazane przez Rytuał Rzymski w 1614 r., a od czasów papieża Benedykta XIV wymagane jest pozwolenie St. Apostolskiej na przechowywanie Najśw. Sakramentu poza ołtarzem ${ }^{63}$ ).

Kraków

Ks. TADEUSZ SZWAGRZYK

\title{
NIEZNANE POLSKIE TEKSTY RELIGIJNE z biblioteki św. Jakuba w Nysie (z XVI w.).
}

W Bibliotece Kapitulnej w Wrocławiu ocalał szczęśliwie w czasie ostatniej wojny światowej rękopis, pochodzący z byłej Biblioteki Parafialnej przy kościele św. Jakuba w Nysie, dzięki temu, że na okres oblężenia Wrocławia był wywieziony poza miasto.

Rękopis pochodzi z XVI wieku, pisany jest w języku łacińskim, zawiera też dodatkowe teksty polskie, wymiary ma $10 \mathrm{~cm} \times 15 \mathrm{~cm}$, kart. 141, oprawiony jest $\mathrm{w}$ deskę i skórę, na przedniej okładce wyciśnięta i złocona postać św. Jana Chrzciciela, tylna zaś ma tłoczone i złocone wzory kwiatowe, oprawa na grzbiecie jest nieco uszkodzona, brak zapinek.

Rękopis ten ma tytuł podany w majuskułach: „C ursus de beata Virgine Maria".

64) Por. J. Danielewicz, Kościół i jego wnętrze, Kielce 1948, s. 75.

65) Conc. Trid., sess. 13, c. VI. (Canones et Decreta Oecumenici Concilii Tridentini, Lipsiae 1887, s. 67).

6) Benedictus XIV, in Const. Accepimus 16 Iulii 1746; (Gasparri, 1. c., II, n. 368). 
Pod względem treściowej zawartości obejmuje on:

„,od k. 2a: Matutinum, k. 19b: Laudes, k. B.4: Ad primam, k. 37a: Ad tertiam, k. 39b: Ad sextam, k. 42a: Ad nonam, k. 44a: Vespere Beate Virginis, k. 49b :Completorium, 53a: Suffragia maiora (między innymi - de Sanctissima Trinitate, de Sancta Cruce, de s. Adalberto, de s. Johanne Baptista, de s. Augustino, Stanislao, Maria Magdalena, pro pace), k. 58b: Septem psalmi penitentiales. Na k. 81a są słowa: „Finis adest - Koniecz maczie“, oraz podany rok rzymskimi cyframi - MDLIII. ${ }_{1}$ W tej części jest pismo jednej ręki. Od k. $81 \mathrm{~b}$ do k. $125 \mathrm{~b}$ jest już pismo innej ręki, mamy tu „Benedictio“ oraz "Sequuntur Vespere et vigilie mortuorum“. Od karty $128 \mathrm{a}$ do $138 \mathrm{~b}$ mamy pismo zasadniczo trzech rąk i polskie teksty.

Pierwsza więc część ma podaną ścisłą datę swego pochodzenia: rok 1553, inne części nie wychodzą też poza ramy XVI wieku. Badanie proweniencji rękopisu nie nastręcza większej trudności od roku 1589, ale trudno rozstrzygnąc jego poprzednią przeszłość. Na przedniej wyklejce okładki mamy adnotację: „Johannes Hancke Anno Domini 1589". Tutaj też jest pisany ręcznie zatarty ekslibris: „Hans Hancken sein buch“, na odwrocie zaś pierwszej karty ochronnej jest zatarty 'również napis „Johannes Hancke des pfarn sohn“, jeszcze bliższe dane o nim są zaznaczone w przekreślonej też później zapisce na karcie 141 a, pisanej o Janie Hancke przez kogoś innego, chociaż w pierwszej osobie:

„Das büchlein ist mir lieb wers mir stilt ist ein dib 1588. Johannes Hancke bin ich genant alle mein tuhn stet inn gottes hand zur Leupa ist mein vatterland geschrieben an Ostern iar 1588".

Niżej zaś jest wyraźnie mowa o pochodzeniu Jana Hancke $\mathrm{z}$,nieprawego łoża“ („Dirnius bin ich genandt"), o urodzeniu poza legalnym małżeństwem:

„Zuhe der Sdros ist sein uaterland. geschriben an disen iar 1588“.

$\mathrm{Na}$ okładce jest jeszcze jedna adnotacja, trudno czytelna, w której piszący prosi osoby wplywowe o polecenie (domini illustrissimi), celem otrzymania stanowiska, aby mógł tam „verbum dei praedicare“. Zapiska brzmi: 
„Mi d. i I (domini illustrissimi), rogo g(ratia) v(estra) dignemini miserum d(omino) $M($...) in Hokowic...(?) commendare, ut sic per vestram commendacionem possim in gibia(?) locum, qui iam diu vacat, nancisci ibique verbum dei praedicare; ego vicissim memor ero vestri beneficii“.

Wymieniona tu miejscowość - Leupa - Leipe - to jest Lipowa Śląska (Deutsch Leipe) koło Grodkowa.

Do ręki Jana Hancke zawędrowała wymieniona ksiązka z innego źródła, widocznie z jakiegoś katolickiego klasztoru, (może Głogów, Wrocław), a pisane modlitwy w polskim języku w formie żeńskiej, świadczyłyby, że kreśliła je jakaś zakonnica, dla modlitwy prywatnej lub wspólnej w klasztorze. Na karcie 125b zaznaczono nawet, że ,Bylla iedna piekna Mniska u myllego s. Franciska..." Dalsze słowa tej samej zapiski sa zgryźliwsze, dlatego je opuszczamy.

Jeślibyśmy wzięli pod uwagę regulę św. Franciszka z Asyżu - to mogłyby tu być wzmiankowane: klaryski, które miały swój klasztor w Wrocławiu, Głogowie, ewentualnie franciszkanki z Jaworu.

Znany kanonik Tinczmann glosił $u$ wrocławskich klarysek często kazania; zważywszy ten moment, że Hancke posiadał téz rękopis z rzekomymi kazaniami Tinczmanna, rodzi się domysł, czy egzemplarz z polskimi tekstami nie pochodzi od klarysek wrocławskich i przez ręce Tinczmanna dostał się do Hanckego. Ale będzie to tylko domysł.

Czy były jakieś łączności klaryselk wrocławskich i głogowskich z innymi ich klasztorami w Polsce: Kraków, Stary Sącz, Zawichost, trudno na ten temat podać wyczerpujace informacje z braku odpowiednich materiałów. Pisze jednak sỉusznie O. Czesław Cezar B a ran w wydanej w Warszawie w 1954 r. pracy pt. „Sprawy narodowościowe u Franciszkanów Sląskich w XIII w." (s. 70), że w klasztorach na Sląsku przez długie wieki liczebną przewagę mają klaryski pochodzenia polskiego". Inaczej było w klasztorach męskich. I tak klasztor franciszkański w Nysie był ,pod silnym wpływem Niemców“ (s. 33), a w niedalekim juz Głogówku konwent „odznaczał się charakterem polskim" (s. 35). Ponieważ w rękopisie $\mathrm{z}$ kazaniami 
(,Tinczmanna“) jest opis pożaru w Głogowie, można przypuszczać, że pochodzi on z Głogowa, może nawet od klarysek.

Inne zapiski dodatkowe podane są w języku łacińskim, zdradzaja silnie protestanckiego ducha. Na pierwszej karcie ochronnej czytamy ,Illumina, domine tenebras cordis mei, et illumina me tuo sancto spiritu, ut semper permaneam in vera et pura doctrina tua“, "Ille nos benedicat, qui sine fine viuit et regnat", „Raro faenix invenitur in mundo, raro etiam concordia monachorum". A dalej "Dimidium facti, qui coepit, habet", i podaje przy tym (Hor. lib. 1 epist). Na wyklejce wewnętrznej drugiej okładki jest jeszcze inna zapiska: „Deus perdat nos impios zophistas, qui tam sceleste detorquamus verum verbum dei, propter nostra somnia vanissima, frustra agimus, frustra agimus, converte nos, o domine, et convertam“. $\mathrm{Na}$ karcie $69 \mathrm{~b}$ jest litania do Wszystkich Swiętych, ale tu juz są silne dodatki protestanckie, i tak po wezwaniu „Sancta Trinitas unus Deus, miserere nobis" dopisano ,cetera omnia frustra - sancta cucula ora pro nobis", czyli dopisujący uważa dalsze wezwania świętych za bezcelowe i wspomina o ,cucula" (kapucyńskim habicie i kapturze). Po słowach "Sancte Petre“ dopisano „Sancta piszalka ora pro papa", a niżej po „sancte Jacobe“ - „viuos male perdant papiste, vos blasuematis deum et filium eius, quem misit, Jesum Christum".

Celem zrozumienia ducha wymienionych zapisek musimy rzucić parę uwag na temat rozwoju protestantyzmu w ziemi nyskiej i grodkowskiej.

Protestantyzm w pierwszej fazie swego rozwoju szerzył się dość gwałtownie na Sląsku, nawet w Nysie pod okiem biskupa znajdował dość licznych zwolenników a liczba katolików malała. W pobliskim Grodkowie znajdowali się również protestanci, ale w mniejszym procencie, aniżeli w Nysie, natomiast w okolicy Grodkowa wielka czesść szlachty skłoniła się ku protestantyzmowi i otworzyła kościoły swego patronatu dla „nowego kultu“ ${ }^{1}$ ). W tym zasięgu protestantyzmu znalazła się

1) Chronik der Stadt Grottkau, Grottkau 1867, 54-55.

J. Soffner, Geschichte der Reformation in Schlesien, Breslau $1887,412$. 
również i Lipowa Slaska ${ }^{2}$ ). Głównym powodem rozwoju protestantyzmu w tej miejscowości były względy natury gospodarczej, a mniej religijne.

Wieś Lipowa Śląska była obowiązana płacić roczne dziesięciny wrocławskim wikariuszom katedralnym. Szczególniejsze natężenie rozwoju protestanckich wpływów w ksiestwie grodkowskim miało miejsce za rządów wrocławskiego biskupa Kaspra z Eogaw. Wielkie skionności dla prostestantyzmu okazywał w tym czasie grodkowski starosta Jerzy Dreske (prawdopodobnie z Marcinkowic Oławskich) w Goli Grodkowskiej. Jego siostra Anna była właścicielka Lipowej Sląskiej, męża miała z Bischofsheim. Po śmierci męża opiekunem jej dzieci był Henryk Skoppe, zaciekły luteranin, właściciel innego majątku w Lipowej. Katolickim proboszczem w Lipowej był Baltazar Reisner (Resner), któremu odmówiono również płacenia należnych dziesięcin. Biskup Kasper zawezwał (18. V. 1563 r.) grodkowskiego starostę do skłonienia poddanych do płacenia dziesięcin katedralnym wikariuszom, 9 kwietnia 1564 roku zewezwał poddanych Skoppa do uiszczenia dziesięcin, 11 października ponowił swe upomnienia, okazały się one jednak całkowicie bezskuteczne. W tym samym roku (1564) Skoppe wypęaził z Lipowej proboszcza Reisnera, wiernym wzbraniał uczęszczać do kościoła i sprowadził jako jego następce ,,polskiego luteranina" Jana Hancke, który najprawdopodobniej był katolickim duchownym i przeszedł na protestantyzm. Tenże pastor i jego syn Maciej dzierżył parafię w Lipowej ponad 30 lat $^{3}$ ). $\mathrm{Na}$ karcie 126 b rękopisu (79 n) są słowa: „factus ergo

2) E. Anders, Geschichte der evangelischen Kirche Schlesiens, Breslau 1883, 47.

3) K. Engelbert, Der Breslauer Bischof Kaspar von Logau (1562-1574) und sein Domkapitel, Archiv für schlesische Kirchengeschichte 7 (1949) 101. Autor korzystal przy opracowaniu artykułu swego jeszcze z materiałów Archiwum Parafialnego w Lipowej Sląskiej. Na moją kwerendę (11. IX. 1955 r.), czy zachowały się po wojnie jakieś materiały archiwalne, które by pomogły ustalić, skąd pochodził Jan Hancke, odpowiedział Urząd Parafialny w Lipowej Sląskiej negatywnie. Wspomniana zapiska mówi ogólnie tylko, że Hancke mial w Lipowej „Vaterland“. Por. też K. Engelbert, Beiträge zur Geschichte des 
presbiter in monasterium clericorum mox instituit et cepit vivere secundum regulam ad sanctis (raczej winno być a sanctis) apostolis constitutam", które świadczyłyby, że jakiś kapłan (przypuszczalnie Hancke) był w klasztorze, później został protestantem, aby żyć wedle reguły ustanowionej przez apostołów. Należy wziąć też pod uwagę, że wykazy protestanckich kaznodziejów z XVI w. nie podają ordynacji Hanckego, czego rzeczywiście nie czyniono, jeśli wstępował do obozu protestantów katolicki duchowny już po otrzymanych święceniach. $\mathrm{Na}$ podstawie dokumentu (listopad 1597 r.) wiemy, że Kasper z Bischofsheim w Lipowej doniósi do księcia Karola z Ziębic, iż administratorzy wrocławskiej diecezji wypędzili protestanckiego duchownego z Lipowej a na jego miejsce osadzili kapłana katolickiego ${ }^{4}$ ). W tym więc czasie skończyliby swe działanie na terenie parafii w Lipowej wspomniani Hanckowie.

Jan Hancke pozostawił oprócz rękopisu ,Cursus de beata Virgine Maria“ (dawna sygnatura IX, 34) jeszcze inny rękopis (dawna sygnatura XLVII, 6), mianowicie kazania rzekomo Tintzmanna.

Rękopis „Cursus de beata Virgine Maria“ dostał się następnie do Biblioteki Parafialnej św. Jakuba w Nysie, znany bibliofil i organizator tejże biblioteki Pan Feliks Ambroży Pedewitz, proboszcz parafii św. Jakuba w roku 1681, miał go już w swym zbiorze, o czym świadczy zapiska proweniencyjna „Bibliothec. Paroch Ecclesiae s. Jacobi Nissae 1681. F. S c h u p pe zapisał go w znanym katalogu pt. Katalog der Bibliothek der katholischen Stadtpfarrei zu Neisse (Nysa 1865, str. 34, nr. 458) jako „Cursus de beata Virgine Maria", manuscriptum recentioris. temporis. Obecnie rękopis ma sygnaturę $79 \mathrm{n}$.

Drugi rękopis pochodzący ze spuścizny po Janie Hancke, to wspomniane rzekomo kazania Mikołaja Tinczmanna. W zachowanym w Bibliotece Kapitulnej w Wrocławiu katalogu Biblioteki Parafialnej św. Jakuba w Nysie, sporządzonym przez

Breslauer Bischofs Kaspar von Logau (1562-1574), Archiv für schlesische Kirchengeschichte 10 (1952) 125, 141-142, 145.

4) Archiwum Archidiecezjalne w- Wrocławiu, MM 5 f. Dokument papierowy, w języku niemieckim. 
wspomnianego Pedewitza (obecna sygnatura 71 n.), pt. „Catalogus universalis Bibliothecae Parochialis Ecclesiae Sancti Jacobi Nissae Anno Domini 1681. VIII. 21" odnośnie do Tinczmanna zaznaczono na karcie 79: „Tintzmani Concionum Libri quinque z. 43, 44, 46, 47“, nie ma wśród nich jednak nr 96, którym oznaczono nasz rękopis, a Schuppe (str. 114, Nr 1520) podal podobnie: „Tintzmanni Nic. Conceptus sermonum mscrpti saec. XVI. Celeb. urbis Glogoviae maioris conflagrationis miranda descriptio ceteris civitatibus ad cautelam".

Mikołaj Tinczann umarł 17. VIII. 1616 r., był scholastykiem kapituły katedralnej w Wrocławiu, ponadto był członkiem kolegiackiej kapituły św. Krzyża w Wrocławiu, kolegiaty w Brzegu i Nysie ${ }^{5}$ ). Obowiązki proboszcza w Nysie pełnił już od roku 1590. Pedewitz w swej historii kościoła św. Jakuba w Nysie pisze, że Tinczmann był człowiekiem „bardzo bogatym“ oraz ,fervens praedicator verbi divini", jego kazania zachowały się w nyskiej bibliotece, ,in multis libris", znał język grecki i hebrajski, był profesorem filozofii, a następnie teologii w Seminarium Duchownym w Wrocławiu.

Kazania zawarte $\mathrm{w}$ naszym rękopisie przypuszczalnie nie pochodzą od samego Tinczmanna, ale raczej od kogoś innego, ponieważ podają lata 1525 do 1529 , a wtedy Tinczmann nie mógł ich pisać, gdyż w 1564 r. został przyjęty dopiero na uniwersytet w Wiedniu, mógł najwyżej je zaczerpnąć z wcześniejszego źródła lub odziedziczyć ${ }^{6}$ ).

$\mathrm{Na}$ przedniej okładce oprawy jest wyciśnięty prawdopodobnie inny właściciel : „Sum D(omini) Celestin“, a na drugiej podany rok: XXXVIII (= 1538).

Kazania zawarte w rękopisie wypełniaja karty $5 \mathrm{~b}$ do 253,

5) G. Zi m m erm a n n, Das Breslauer Domkapitel im Zeitalter der Reformation und Gegenreformation (1500-1600), Weimar 1938, 542-545.

6) J. F. Pedewitz, Historia ecclesiastica ecclesiae Parochialis s. Jacobi Nissae, Neisse 1905, 73-74.

H. Hoffmann, Die Geschichte des Breslauer Alumnats, Breslau 1935, s. 43.

H. Je din, Der Breslauer Kanonikus und Pfarrer von Neisse Nikolaus Tintzmann $(\dagger 1616)$ als Prediger, Archiv für schles. Kirchengeschichte 5 (1940), 142-151: 
zaczynają się od słów ewangelii „Exiens Jesus de finibus Tyri venit per Sidonem ad mare Galilee", na kartach 254 do 259 podany jest opis pożaru miasta Głogowa, który miał miejsce w końcu września 1517 roku, „Celeberrimae urbis Glogoviae Maioris conflagrationis mirandae descriptio ceteris civitatibus in cautelam", na ostatniej karcie 265 sa zapiski z roku 1574 o wrocławskim biskupie Marcinie Gerstmannie.

$\mathrm{Na}$ przedniej karcie ochronnej jest najpierw zapiska proweniencyjna "Sum ex libris Johannis Hanckii parochi in Leippa Anno 1584 gratia deo et danti" a pod nią słowa ,Beuchten ohne Reuhe, lieben ohne treuhe, Betgenn ohn Inickeit, Sindt dred verlone arbeithe". Na pierwszej wyklejce wewnętrznej jest uwaga „Leichenpredigt oder tröstliche Vermahnung bei dem Begräbnis durch Dominicum Schoenfeldt Pfarrer zu Brigen". Czy kazania te powstały w Glogowie czy w Brzegu i jakim sposobem dostały się do rąk Jana Hancke trudno odgadnąć.

Tyle wiadomości posiadamy o Janie Hancke i jego rękopisach, które dostały się do Biblioteki Parafialnej św. Jakuba w Nysie, a następnie do Biblioteki Kapitulnej w Wrocławiu.

Dla polskiego badacza szczególniej ciekawy jest rękiopis pierwszy, mianowicie „Cursus de Beata Virgine Maria“ ze względu na zawarte w nim teksty polskie. Porównanie charakteru pisma w notatkach proweniencyjnych Jana Hanckego z pismem polskich modlitw, zarówno „Prosy o Duchu św.“ jak też i innych modlitw prowadzi nas do zdania, że nie pochodzą one $\mathrm{z}$ ręki Hanckego, ale są dziełem innej ręki. Charakter pisma w tekście „Prosa o św. Duchu“ jest inny od pisma w tekście modlitw, mówiących o 1) wybraniu Matki Bożej, 2) Zwiastowaniu, 3) Narodzeniu Pana Jezusa, 4) pokłonie Trzech Królów, 5) Znalezieniu Pana Jezusa w świątyni, 6) ukazaniu się Pana Jezusa po Zmartwychwstaniu, 7) Wniebowstąpieniu Pana Jezusa, 8) Zesłaniu Ducha św., 9 )Wniebowzięciu Matki Bożej. 10) Ukoronowaniu w niebie Matki Bożej. Modlitw dziękczynnych mamy cztery.

Zaczniemy najpierw od sekwencji o Duchu świętym. Ks. B. Gładysz pisze, że twórczość sekwencyjna w Polsce była już dość ożywiona w początkach XV wieku, wzmogła się do punktu szczytowego na przełomie XV wieku i XVI, osłabła 
w pierwszej połowie XVI wieku i znalazła swój kres w reformie soboru trydenckiego ${ }^{7}$ ). Tenże autor uważa za sekwencje pochodzenia polskiego najpierw te, które 1) spotykamy wyłącznie w polskich źródłach rękopiśmiennych lub drukowanych, 2) które mieszczą się w źródłach obcych, ale późniejszego pochodzenia, aniżeli polskie, pojawiły się w Polsce i z polskich źródeł zostały przyjęte do zagranicznych rękopisów i druków, 3) które spotykamy we wcześniejszych źródłach obcych, aniżeli polskich, ale wyraźne cechy wewnętrzne wskazują na polskie ich pochodzenie $^{8}$ ).

W naszym rękopisie autor tłumaczy z języka łacińskiego tekst „Veni Sancte Spiritus“ na język polski. Miejscem tłumaczenia jest prawdopodobnie Sląsk, w tłumaczeniu dają się odczuć pewne wpływy czeskie. W tej sprawie musza wypowiedzieć się jeszcze językoznawcy, aby ustalić pewniej środowisko powstania tłumaczenia.

Sekwencja „Veni Sancte Spiritus“ przypisywana jest papieżowi Innocentemu. III; poprzednio stosowana była na jej miejscu sekwencja "Sancti Spiritus adsit nobis gratia" (autorstwa mnicha Notkera z St. Gallen) ${ }^{9}$ ).

Najstarszy tekst polski „Veni Sancte Spiritus et emitte coelitus" (Prosa o Duchu świętim) wydał M. B o b o ws ki w 1893 roku $\left.{ }^{10}\right)$ :

„Zawitay duchu święti

A Promień światloscy twey

Rac nam ź nieba darowac“.

Tekst jest inny od naszego, omawianego rçkopisu.

W rękopisie z Biblioteki Parafialnej w Nysie „Prosa o s. Duchu" mieści się na kartach 134 a do 135 b. Tekst brzmi następująco:

7) B. Gładysz, Łacińskie sekwencje mszalne z polskich źródeł średniowiecznych, Ateneum Kapłańskie 40 (1937) 265.

8) tamże 33 (1934) 113.

9) Analecta hymnica medii aevi, Leipzig 1915, t. 54, 237.

I. Schuster, Liber sacramentorum, Regensburg (1929), tom IV.

10) M. B obowski, Polskie pieśni katolickie od najdawniejszych czasów do końca XVI wieku, Kraków 1893, 232-234. 
Prosa: o: s: Duchu

k. 134 a.

Veni sancte spiritus et emite

celijtus Lucis tue radium

Przidzy duchu swyenty knam

a racz spuszczicz swysokosczy

promyen twoiey milosczy

Veni pater pauperum veni dator

munerum veni lumen cordium.

Przidzy oycze syroth ubogich przi

dzy dawcza daruw 1) bogatich

przidzi swyczo serdeczna

k. 134 b.

Consolator optime dulcis hospes

anime dulce refrigerium.

O naleyepssy nas pocziessyczielu

slotky goscziu dusse moiey

slodzyuchne ochladzeny.

In labore requies in estu temperies

in fletu solacium

Ty ies w praczy odpoczynieny

w rzeniu ochlodzenie $\mathrm{w}$ placzu

yedyne pocziesseny.

O lux beatissima reple cordis intima

tuorum fidelium

O nasweyentssa swiatlosczy napel

ni nasse wnetrnoszy slug

twoich milich.

k. 135 a.

Sine tuo numine nihil est in homine nihil innoxium.

Panie przes twoiego daru nie

mas nicz tak w czlowiecze nie

mas nicz niewinnego.

Laua quod est sordidum riga

quod est aridum sana quod est saucium.

Racz omicz czo iest smrodlywego

pokropicz czo iest suchego us

drowicz czo iest rannego.

Flecte quod est ridigum foue

quod est frigidum rege quod est devium

Racz sklonicz czo iest hardego

Zagrzey czo iest zymnego racz

rzundzicz blandzanczego. 
k. 135 b.

Da tuis fidelibus in te confitentibus

Sacrum septenarium.

Racz dacz twoym wiernym slu

gam w tobie wiernie uphaiun

czim syedmioraky dar swienty.

Da virtutibus meritum da salutis

exitum da perhenne gaudium.

Racz dacz cznotliwe pomieska

ny zbawienne day skonany

po smyerczy wieczne wesely.

Forma poetycka przytoczonego tłumaczenia, jak widzimy, jest słaba, a tłumacz starał się raczej o dosłowne oddanie myśli tekstu łacińskiej sekwencji, co mu się nieźle udało. Zachodzi tylko jeszcze pytanie, czy tłumacz nie skorzystał z innego źródła, które mu było dostępne przy tłumaczeniu? Może tėz rozbiór językoznawczy tegoż tekstu umieści go w innych ramach chro_ nologicznych?

Następną osobliwością rękopisu są polskie teksty modlitw. Trudno orzec, czy są one utworem własnym, czy odpisem $z$ innego źródła. Pisała je niewiasta, zapewne jakaś zakonnica, ponieważ zwroty są w żeńskiej formie. Modlitwy zaczynają się na karcie 128 a i ciągną się do karty 134 a. Przed każdą modlitwą jest uwaga - jak należy odmawiać daną modlitwę.

\section{Modlitwa pierwsza}

\section{...Stoiacz}

Pieruei mow dziessiecz Zdrowych

marii potim kliekni na kolana mo:

wiacz the modlitwe.

O panno nasswiethssa maria wpominam:

czie wielkych niewimownych radosscziach

y czczi ktore dussa twoya i czialo przy

elo gdy czie bog ocziecz ssin y duch

sswienthy wybral od wyekow w radzie

troyczie sswyenthej a stwarzil czie pirwej

nyzly nyebo y. wssythky insse

rzeczy panno nasswyethssa maria ma:

thko boga nawissego uczin mye ucze:

ssnyczka twoich wylkych radossczy $u$ :

kass my laske twoje dlya mego (2) upo

mynanya y prossby wysluchay mye

podlug wielkiey potczeby moiey. Amen“. 


\section{Modlitwa druga}

Mow dziessiecz zdrowich maryi

Stoiancz a modlitwe klieczacz.

O panno maria upominam czie wielkiech

czczy y chwaly która dussa twoya i

czialo prziele gdych angiel gabriel

zwiastowal y zess mathka boza myala

ssie stacz a panna bycz przy porodze

nyu y po porodzenyu gdy rzek angiel

Zdrowass maria lasky pelna pan

s tobą blogoslawyenass ty myedzy

nyewyastamy y blogoslawyon:

owocz ziwotha twego gdyss panno

ty sslowa porozumyala tedyss

uznala boga oycza dobrocz syna

mylossierdzie ducha swietego ma

drosscz y rzeklass otho ya ssluzebni

czka boga pana mego stan ssye

mnyo podlug slowa twego wolia

boska nyechay bendzie we mnye wy

pelnyona a w tych sslowach panno na:

sswiethssa byla napelnyona ducha

sswiethego a ssin bozy othpoczywal

pod sserczem twym panyensskym:

dziewyecz myessaczow przetho czie

panna nasswiethssa upominam twych

wielkych radosczy abyss mye grze

ssna pocziessila podlug lassky

twojey y wielkiey potrzeby moiey.

\section{Modlitwa trzecia}

Mow stoiacz Dziessiecz Zdrowich

marii a modlitwe klieczacz.

O nasswyethssa panno maria upo

mynam czie wyelkych radosczy

ezczy y chwaly ktory dussa

twoia y czialo bylo obdarzone

onei noczy gdiss ssina twego

namilieissego porodzila przess

wssithkiei przirodzonej boleyessczi

a czistass panna zostala przi po

rodzenyu i po porodzenyu panno

nasswiethssa maria tej godziny

bilo twe wesselye tak wielkie 
i zess na twego milego ssina cze

stho krocz laskawie patrzila

i milossnye pogladala w two

ichess go reku piastowala

i od wielkiei radossczi niewiedzia

lass gdziess bila panno maria

dlia tych wielkich radossczy

ktoress miala tei noczy y dlya

pokornej prossby moiej wislu-

chay mie podlug niewimownej

lasky twoiei y wielkiej potrze-

by moiej. Amen.

\section{Modlitwa czwarta}

W tej modlitwie od karty 130 b jest pismo innej ręki, nieco drobniejsze.

Mow 10 Zdrowych mary stoiacz

a modlitwe klieczacz.

O panno maria mathko pana

boga nawissego upominam

czye wielkich radosczy czczy y chwaly

ktore dusse thwoie y czyalo przyelo,

gdy trzey krolowie poczczywie dary

przyniesly thwemu namylssemu synowy

zlotho myra kadzydlo napyrwssy byly

ktorzy czyebie $y$ thwego namylssego syna

uczczyly y uznaly yss byll prawdzywy

Bog czlowiek y pan wssiszkiego sthworzenya

Panno Maria dla twych radosczy y poczye:

ssenya ktoresz myala od twych swiethich

Trzech krolow racz mye poczyessycz y wy

ssluchacz podług lasky thwey y wielkiey

potrzeby moyey Amen.

\section{Modlitwa piąta}

Mow dzyessiecz Zdrowasz Maria

Stoyacz a modlythwe kleczacz.

O panno Maria dla wielkych radoszczy

ktoress myała gdiss thwego namylssego syna

Trzeciego dnya w kosczyele nalazła wye:

działass yss thwoy namylssy syn myal umrzecz

A yzess niewiedzyala kiedy dla thego bel

thwoy smuthek wielky ale gdyss go 
nalazła thedy nye bylo $w$ tobie zadnego członka ktoryby ossoblywym wesselym y radossczyam nie beł napełnyon Panno Maria raczy mye pocziessycz podlug wyelkiego mylossierdzya Twego y wielkiey potrzeby moyey. Amen.

\section{Modlitwa szósta}

Mow stoyacz dzyessiecz zdrowych

Mary a modlithwe kleczacz.

O panno Maria naswieczssa wpomynam czie $\mathrm{z}$ onego wielkiego wessela y radossczy kto res myala w dzyen wielkonoczny gdych ssye Thwoy namylssy sin ukazal a slotko czye poczyessyl po wielkym ssmuthku thwoym pothim sie ukazal Mariey Magdalenye y sswym namylssym zwolenikom ktorzy thes w wiel: kym smuthku byly przess tho wyelkye wessele Panno Maria nasswieczssa racz mye grzessna poczyessycz y wyssluchacz podług nyewymowney łasky thwoyey a wielkiey potrzeby moyey. Amen .

\section{Modlitwa siódma}

Mow sthoyacz dziesiech Ave maria a modlitwę kleczacz.

O Panno moya Maria upomynam czye onych wielkych radosczy y wessela ktoress myala onego czassu gdy thwoy Namy: leyssy syn w nyebo wsstepował s thymy wssythkymy ktore byl sprzed pyekla wywiodl Panno Maria Thwe wessele beło w ty czassy nad wssytky wessela, bossz przegladała przess wssyczkie hory An: yelskie y wydzialasz on stholecz ktorym thwoy myly ssin zgothowal y ssprawil z madrossczy Boskiey o panno Maria smyluy ssie na demnam dla thego wiel: kiego thwego sserdecznego wessela, pocziesz ssmuthne ssercze moye wy: sluchay pokorna prazbe moye a smyluy ssie na demnam podlug lasky thwoiey a wielkiey potrzeby moyey. Amen. 


\section{Modlitwa ósma}

Mow dziessiecz Zdrowych Mary

Sthoyacz a modlythwe kleczacz.

O Pany Moya Nalutossczywssa Maria upomynam twa nasswiethssa mylosscz onych wielkych radossczy czczy y chwaly ktorymyssz beła obdarzona w dzyen swyatheczny gdy wssytczy Apostolowie przy thobie siedziely zamknionymy drzwyamy dla Boyazny zydowsskiey kiedy przyssedl twoy myly ssin y na: pelnyl wasz wssythkych Duchem sswietym Thak y zessczie ssie wieczey nye baly , zydow any zadney grozby sswyata thego alessczye yawnye wyznawaly wiare sswyntha krzessczynsska dla: thego poczyessenya ktoresz naswietssa Panno myala s przyeczya ducha sswie: thego poczies mye y wyssluchay mye podlug nyewymownego Milosierdza Thwego y podlug uczysku sercza mego. Amen.

\section{Mődlitwa dziewiąta}

Mow stoyacz dziessiecz zdrowich Mary sthoyacz a modlitwe kleczacz.

O Nayassnieyssa gwiazdo morska Panno Maria upomynam czye wiel: kich radoszczy czczy y wessela ktoress myala gdy thwoy myly do czyebye posslal Anyola Gabryela ktory rzekl poydzyess IMyla panno $\mathrm{s}$ tego myzernego sswyatha do chwaly y do radossczy wieczney a nathychmyasth sie wssy: ssczy Apostoly zebraly a w thym przyssedl thwoy Myly sin ze wssytkam rzessam Niebieska wzyal czye y prowadzyl czye przess dzyewyecz horow Anyelskych tamesz bela az do ezwarthego dnya a ad koss: dego była ossoblywa chwala y czesscz ukazana, O Namylossiernyeyssa poczyessyczyelko wssytkych ssmutnich w czye duffayaczych ssmyluy ssye nad namy podlug lasky thwoyey y wielkiey potrzeby moyey. Amen. 


\section{Modlitwa dziesiąta}

Przy tej modlitwie jest podana uwaga $w$ innej formie.

Thu sspay Dzyessicez Zdrowych

Mariy stoyacz a poklenknawssy mow.

O Nasswiethssa panno Maria Ma-

thuchno Boga wssechmogaczego pa:

na Jesti Christa napomynam czye

w obffitossczy wessela, w poczlywossczy

y w dosstoynossczy ktore czyalo y

dussa twoya nasswiethssa usznała

dnya czterdziestego kiedy czye

Thwoy myly sin chwalebnye na

dziessiati sstolecz chwaly krole:

sstwa niebiesskiego powyzssył y

bliską czye Troyczy swiethey

uczyny1 a mocz y pansthwo tobye

nad wssytkiemy rzeczamy thaliye

dał y ukazal na nyebye y na ziemy

y ukoronowal czyebye koroną nye:

bieską dwonasthoma gwiazdoma

Salamonowych sprawiona a we:

zwanas yest Matuchna Wielkiego

Miłosierdzia o nasswietssa panno

Maria Matuchno Boga wssechmo:

gaczego: Proszę czie dla niewy:

mownego wessela y dostoynosczy

thwey smyluy ssie nademnam

grzessnam a wissluchay modlytwę

moye niedostoyną racz my dacz

to o czo twey naswietssey mylosczy

zadam podlug lasky thwey nasswiet :

ssey $y$ tesz potrzeby moyey. Amen.

Od karty 135 b mamy znowu inny charakter pisma, odmienny od reki pierwszej i drugiej. Modiitwy mają charakter dziękczynny.

Dziekowanie Bogu oiczu.

Boncz thobie czesc y

chwala boze oicze, zes

nass stuorziel, a stuorzie

nye suoye rzyądzysz

opatruyesz y we wsem

wspomagas. Zachoway 
y nas o boze oycze.

prosim czie przy lascze

swey naswientssey

oyczowskiey od dzysiey

szey godzyny asz na wieki

wiekom. Amen.

$$
\text { (Synowi) „Filio“. }
$$

Bancz thobie czesc y chwala

panie Jesu Chr(yst)e ukrzizo-

vany zes nas wikupiel

y za grziechy nasze bogu

oiczu dosicz uczyniel, przies

smiercz suoie racz o nas

prosym czie pracza miecz.

iako pan y pastyrz nam

od boga oicza nyebieskie

go dany thy sam nasz

wspomagay y godne

czyn ku lascze oicza

swego namilszego. Amen.

(Duchowi św.) „Spu Sancto“.

Bancz thobie czesc y chwała boze duchu swienthy ktory serca nasse rosuiecziel

pocziesil y ku posnanyu

ymienia bozego sprawicz

raczyl, prossym czie o ty

poczieszyczielu duchu s.

racz grziessne sercza

nasze rzyądzicz y spra-

uouacz a moczą y tesz

laską suoya naswieth:

szą, prosym czie ku wsem

dobrem racz pobudzacz.

cziemnosczy nassey nie-

umyeiednosczy racz

oswieczacz ku swiathloscy

racz nass rzedzicz y

sprauouacz y we wsitkich smuth-

kach naszych niedostath-

kach racz na wszythkim

wspomagacz y sam

czieszycz Boze oicze y sinu

y duchu swienthy, boze

w throyczy iedyny racz 
sie smilouacz nad

wsitkymy namy. Amen.

Alia or(ati)o vera deo accepta

O wsechmogaczy wyekuysty

oycze nasszega pana iesu $\mathrm{x}$ (rista)a.

ktoris $\mathrm{z}$ wielkiey swey nigdi

nieskonczoney miłosczy

s placzu naszego mąk wyeku-

ystich czieskich piekielnich,

raczylesz sie o boze oicze ulutovacz

a nas wyrwacz przis nie vinna

a gorzką męke sina twego

iesu $\mathrm{Chr}$ (ist)a niebieskiego

thobie $\mathrm{w}$ bostwye rownego: ktore

musz dopuscziel duchem swietym (3)

w zyuoth czystey panny Mariey

wstąmpiel a $\mathrm{z}$ niey vede (4)

czlowieczenstwa narodziel $\mathrm{z}$ mi:

losczy wielkiey $\mathrm{ku}$ czlowieku

grziessnemu podyąl sie sin twoy

namileyszy grziechu nassego.

Jako sei go skoro podyąl

o boze oycze nie czaless (5) thego czier:

piecz any thego chezyalo twe

naswiethsze bostwo wstrzymacz

raczylesz go wydacz na meky

okrutne, byczowacz ukrzyzo.

y umrziecz a tho wszythko dla

naszich zlosczy nieprawosci

a czieskich grziechow.

O boze oycze przies okruthne

a czieskie męky niewynną smiercz

sina twego iedinego namilssego

Jesu chr(ist)a pana naszego

my ubogie neczne grziesne

stuorzienie twoye pokornie

serdecznie milosczywie cziebie

zandamy aby thy o namilosczy

wszy oicze raczyl nass wysłuchacz

a nam tho wsythko dacz o czo bissmi

twey. s. milosczy proszyly o mili

oycze mi moczno wyerzyemy

slowam. s. sina twego milego

ktore on swemy nas usthy (6) 
raczyl movicz rziekacz tak

zaprav: zaprav: movie vam

o czokolwiek bendzieczie zendacz

a prosicz oycza mego $v$ ymie

moye wsytko vesmieczie.

Przytoczone wyżej modlitwy ku czci Matki Bożej są przypuszczalnie modlitwami różańcowymi, stanowią one razem z modlitwami dziękczynnymi nie tylko wyraz ducha pobożności pewnego środowiska śląskiego, ale równocześnie są dowodem stosowania polskiej mowy w modlitwie w kołach ziemi śląskiej. Uwagi do tekstu

(1) Tak w rękopisie. (2) Słowo trudno czytelne. (3) Trudno czytelne. (4) Tak w rękopisic. (5) Trudno czytelne. (6) Może naswietszymi (najświętszymi).

Wrocław

Ks. WINCENTY URBAN

PROROCTWO MALACHIASZA O OFIERZE CZYSTEd $(1,11)$

„Ab ortu enim solis usque ad occasum magnum est nomen meum in gentibus; et in omni loco sacrificatur et offertur nomini meo oblatio munda... dicit Dominus exercituum".

Znapa przepowiednia proroka Malachiasza o Ofierze czystej omawiana jest obszernie w dogmatyce w traktacie o Mszy św. Ważność tego tekstu nie ulega wątpliwości i stąd warto rozpatrzyć go dokładnie według zasad egzegezy i filologii, aby w ten sposób przygotować jego dogmatyczne zgłębienie.

\section{USTALENIE TEKSTU WIERSZA}

Krytyka tekstu Mal. 1, 11 stwierdza jego autentyczność i nieskażoność. Tekst hebrajskich kodeksów, jak i ich tłumaczenie na inne języki (głównic LXX), dają treść zrozumiałą, bez żadnych opuszczeń. Całość wiersza 11, tak co do formy i treści, łączy się ściśle z kontekstem. Stąd nieliczni tylko są autorzy kwestionujący wartość krytyczną naszego tekstu $\left.{ }^{1}\right)$.

$\left.{ }^{1}\right)$ Nieuzasadnione krytycznie są propozycje usunięcia pewnych części wiersza jako dodatków: Wellhausen usuwa muqtầ, Nowack i Marti muggasz, Müller (R. B. 1896) i Riessler minchâh tehôrah (element istotny wiersza). Z rowszych egzegetów osamotnieni na swej krańcowej pozycji są Horst F. (Hardbuch zum A. T., Tübingen 1938) oraz Elliger K. (Das Buch der zwölf Propheten, t. II) Nahum-Maleachi, (Das Alte Testament Deutsch, t. XXV, 1950), którzy za późniejszy. wtręt pozba- 